Recorregut de recerca geològica per les comarques de l'Alt Urgell i de la Cerdanya: des de Montferrer i Castellciutat a la Seu d'Urgell, Pont de Bar, Martinet, a Prullans i a Bellver de Cerdanya

Josep Maria Mata-Perelló

Joaquim Sanz Balagué

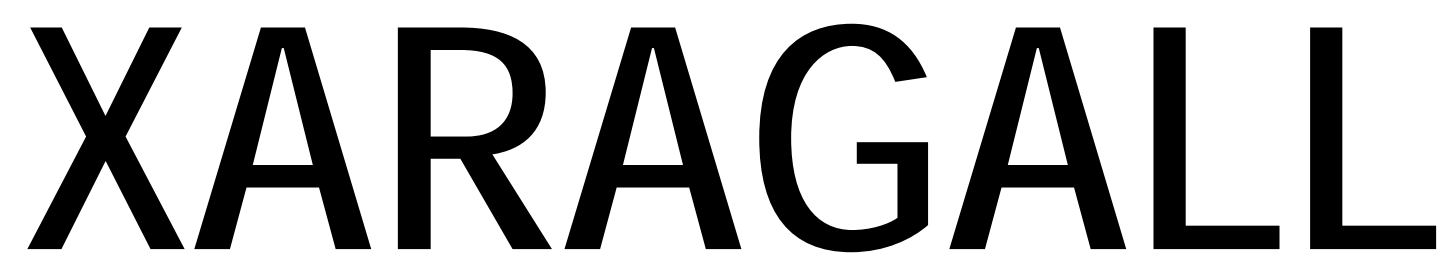

REVISTA DE CIÈNCIES DE LA CATALUNYA CENTRAL n. 7

JULIOL 2015 


\title{
RECORREGUT DE RECERCA GEOLÒGICA PER LES COMARQUES DE L'ALT URGELL I DE LA CERDANYA: DES DE MONTFERRER I CASTELLCIUTAT A LA SEU D'URGELL, PONT DE BAR, MARTINET, A PRULLANS I A BELLVER DE CERDANYA
}

\author{
Josep Maria Mata-Perelló \\ Museu de geologia Valentí Masachs, Escola Politècnica Superior d'Enginyeria de Manresa \\ (EPSEM), Universitat Politècnica de Catalunya · BarcelonaTech (UPC), 08272 Manresa, Spain
}

\section{Joaquim Sanz Balagué}

Departament d'Enginyeria Minera i Recursos Naturals (EMRN), Escola Politècnica Superior d'Enginyeria de Manresa (EPSEM), Universitat Politècnica de Catalunya - BarcelonaTech (UPC), 08272 Manresa, Spain

Paraules clau: Sistema Pirinenc, Patrimoni miner

\begin{abstract}
Resum
Itinerari realitzat el 15 de juliol de 2014. En aquesta ocasió, el recorregut de l'itinerari discorrerà, en la seva totalitat pel Sistema Pirinenc. Més concretament ho farà per diferents sectors dels que componen aquesta unitat, per la seva Unitat Sudpirinenca Central (tradicionalment coneguda amb el nom de les Serres Exteriors Prepirinenques), per la Depressió de l'Urgellet, per la Depressió de la Cerdanya i també pels Apilaments Antiformes de la Zona Axial Pirinenca.

De fet, el recorregut de l'itinerari s'iniciarà dintre de la Depressió de l'Urgellet (tot i que molt a prop d'una cunya de la Zona Axial). Més endavant, després de circular per aquest sector , s'entrarà al Mantell del Cadí. A partir d'aquí, una bona part del recorregut, anirà per la zona de contacte d'aquest mantell, amb els Apilaments Antiformes de la Zona Axial Pirinenca. I, finalment, el recorregut clourà dintre de la Depressió de la Cerdanya.
\end{abstract}

També cal dir, que el recorregut de l'itinerari discorrerà per una sola comarca: la de l'Alt Urgell, des d’Adrall als Arenys de Bar. Després, des de Martinet a Bellver de Cerdanya, es transitarà per la comarca de la Cerdanya.

Xaragall.2015 n.7 | Recorregut de recerca geològica per les comarques de l'Alt Urgell i de la Cerdanya: des de Montferrer i Castellciutat a la Seu d’Urgell, Pont de Bar, Martinet, a Prullans i a Bellver de Cerdanya 


\section{Objectius fonamentals}

Els objectius d'aquest itinerari es concretaran en diversos aspectes, geològics i mineralògics que apuntarem a continuació, d'acord amb el sentit de la marxa.

1. Reconeixement dels Apilaments Antiformes de la Zona Axial Pirinenca i dels materials de I'Ordovicià que la constitueixen. Tanmateix, trobarem afloraments granítics (i granodiorítics) del Carbonífer. Aquesta unitat la trobarem a Castellciutat, en una cunya. I també al llarg de diferents sectors del recorregut, pels voltants de Martinet i Musser, entre altres indrets de l'itinerari..

2. Reconeixement dels materials del Mantell del Cadí, els quals es tallaran cap a la fi del recorregut, entre les poblacions d'Alàs i els Arenys de Bar. Aquests materials, dintre d'aquesta part del recorregut de l'itinerari, seran exclusivament paleozoics, de l'Ordovicià, del Silurià i del Devonià, segons els indrets del recorregut.

3. Reconeixement dels materials terciaris i quaternaris que reblen la Depressió de I'Urgellet. Aquests materials els trobarem entre les immediacions de les poblacions d'Adrall i d'Alàs. Cal dir que els materials terciaris són exclusivament neògens, del Pliocè i del Miocè; i també del Pleistocè i de l'Holocè, segons els llocs.

4. Reconeixement dels materials terciaris i quaternaris que reblen la Depressió de la Cerdanya, de característiques molt semblants a la de l'Urgellet. Aquests materials els trobarem entre les immediacions de les poblacions de Prullans i All. Cal dir que els materials terciaris són exclusivament neògens, del Pliocè i del Miocè; i també del Pleistocè i de l'Holocè.

5. Observació dels contactes entre les unitats geològiques esmentades als apartats anteriors. Aquest contacte es realitza per fractura. Així, en aquest recorregut, travessarem aquesta fractura prop d’Alàs.

6. Observació de les diferents mineralitzacions que anirem trobant al llarg del recorregut, especialment les mineralitzacions ferruginoses $i$ cupríferes associades a skarn, que trobarem prop dels Arenys de Bar i de Musser

7. Observació de les explotacions mineres relacionades amb les mineralitzacions anteriors, i d'altres com les relacionades amb l'explotació d'àrids per a la construcció, que veurem a diferents indrets del recorregut de l'itinerari.

8. Observació de les restauracions (naturals o artificials) realitzades sobre les explotacions acabades d'esmentar.

9. Observació dels diferents indrets relacionats amb el nostre Patrimoni Geològic i amb el Patrimoni Miner que es vagin trobant al llarg del recorregut. 


\section{Antecedents}

En relació a aquest recorregut, coneixem de la existència de diferents recorreguts nostres. Es tracta dels de MATA-PERELLÓ (1995, 1998, 2007 i 2011), així com de MATA-PERELLO i MONTANÉ (2002 i 2004). Tret d'aquests, no en coneixem l'existència de cap altre itinerari que discorri per aquesta zona.

Pel que fa a les mineralitzacions que veurem en aquest itinerari, cal dir que ja estat prèviament descrites per nosaltres en MATA-PERELLÓ (1991), en un treball relatiu al conjunt de les comarques catalanes.

I pel que fa a l'estructura geològica, ens remetrem als treballs de RIBA et altri (1976), i a GUIMERÀ et altri (1992). Tots dos fan referència al conjunt del caràcters geològics dels Països Catalans.

Així, totes aquestes referències bibliogràfiques es trobaran convenientment relacionades dintre del apartat dedicat a la REFERĖNCIES BIBLIOGRÀFIQUES, al qual ens remetem.

\section{Recorregut de l'itinerari}

El recorregut del present itinerari s'iniciarà per les immediacions de la població de de Montferrer. Des d'aquí ens caldrà seguir cap a les immediacions de Castellbò i d'Arcabell, per on farem la primera aturada, a uns $5-6 \mathrm{Km}$ des de l'inici del recorregut a Montferrer. Aquest recorregut es farà seguint la carretera local de Castellbó, sortint de la ruta $\mathrm{N}-260$ a la cruilla de Montferrer.

Tot seguit es retornarà per la carretera nacional N-260, per tal d'anar cap a Castellciutat. En aquesta darrera població, molt propera a la Seu d'Urgell, es realitzarà una nova aturada del recorregut d'aquest itinerari.

Després, el recorregut es dirigirà cap a la Seu d'Urgell, des d'on es seguirà cap al llevant, passant per les immediacions d'Alàs, seguint sempre per la carretera $\mathrm{N}-260$. Més endavant, en arribar al Pont d'Arseguel, es farà una fillola per la carretera local LV - 4052, per tal d'anar cap als pobles d'Ansovell i Cava). Després, caldrà retornar a la carretera $N-260$, per la qual s' arribarà al Pont de Bar, per on es farà una nova aturada.

Finalment, el recorregut es dirigirà cap a les immediacions dels Arenys de Bar, per on es farà una nova aturada d'aquest recorregut. Després, el recorregut continuarà cap a Prullans i Bellver de Cerdanya, per on finalitzarà. 


\section{Advertiments previs}

Com en altres recorreguts de RECERCA GEOLÒGICA I MINERALÒGICA ..., si es disposa del temps suficient, poden efectuar-se passant per totes les parades i filloles. En cas contrari, recomanem prescindir de les anomenades PARADES - CONDICIONALS.

Recomanem, per d'altra banda, tenir una absoluta cura envers de la Natura, tant al llarg del recorregut, com fora d'ell, en tot moment.

\section{Descripció de l'itinerari}

En aquest recorregut hem situat, com ja és habitual en tots els itineraris, una sèrie d'ESTACIONS o de PARADES, que anirem veient a continuació. En cada cas, els hi donarem una denominació que podrà correspondre a algun paratge proper.

Per altra banda, en cada una de les parades, indicarem entre parèntesi el número del "Mapa Topográfico", a escala 1:50.000 editat per I'Instituto Geografico y Catastral, on es troba situada la parada considerada. En aquesta ocasió serà algú dels dos següents: 215 (o de la Seu d’Urgell) i 216 (o de Puigcerdà). Així doncs, la relació ordenada de les aturades que formen part del recorregut del present itinerari, és el següent:

\subsection{Parada 1. CARRETERA A ARCABELL, (terme municipal de Montferrer - Castellbò, comarca de l'Alt Urgell). (Full 215).}

El recorregut del present itinerari cal iniciar-lo a la població de Montferrer; i més concretament, cal fer-ho a la cruillla de la carretera doble N - 260 / C-14 amb la carretera local de Castellbó. Així, caldrà agafar aquesta darrera carretera, per tal d'anar cap a les proximitats del poble d'Arcabell, per on farem la primera aturada d'aquest itinerari. Així, des de la sortida, haurem recorregut uns 5 - $6 \mathrm{Km}$, aproximadament.

En aquest tram, haurem travessat la Depressió de I'Urgellet, on estem ara situats. De fet, Adrall ja es troba a l'extrem occidental de la mateixa. Així, haurem circulat per sobre dels afloraments cenozoics (mio-pliocènics) que la reblen, en part recoberts per terrenys quaternaris.

Des de l'indret de l'aturada, es pot veure un bon aflorament d'aquests materials cenozoics, amb bons exemples de xaragalls i de "barrets de fades", desenvolupats sobre les alternances argiloses i sorrenques. (fotografia 1). 


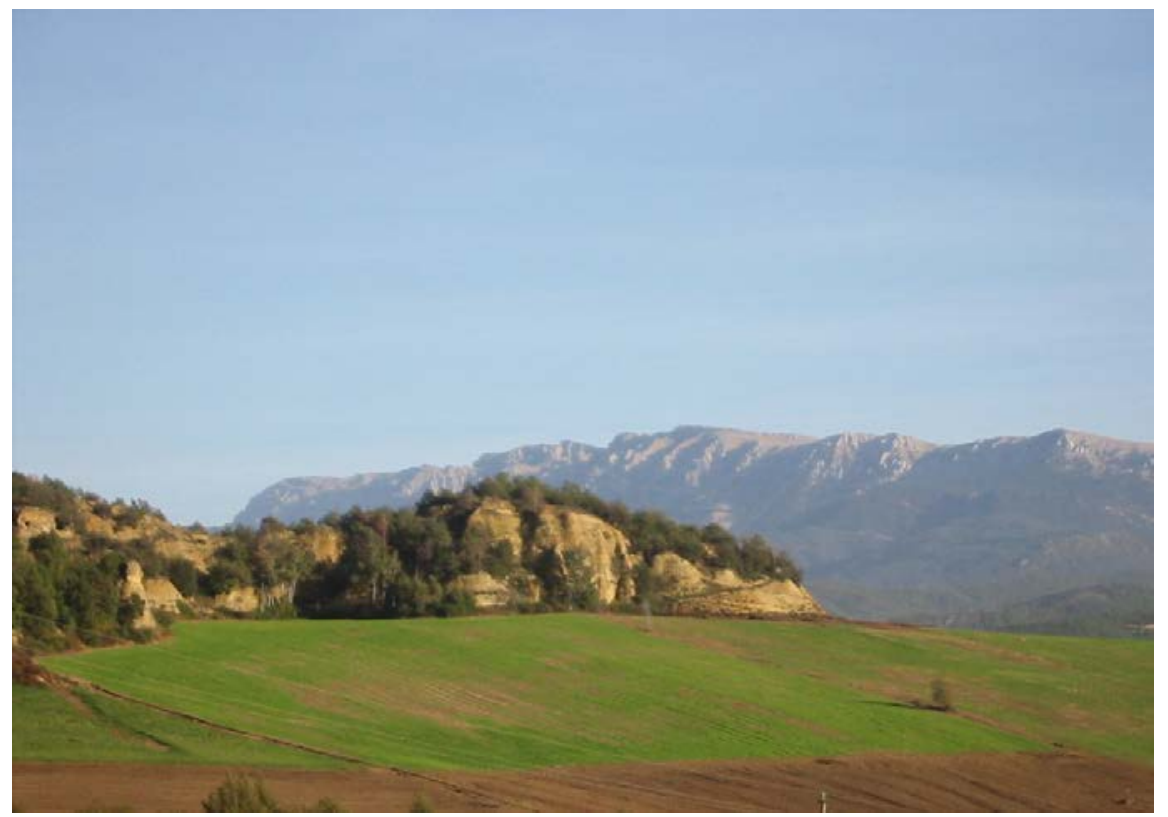

Fotografia 1. Afloraments dels materials cenozoics de la Depressió de I'Urgellet.

Al fons: la Serra del Cadí

\subsection{Parada 2. MIRADOR DE CASTELLCIUTAT, (Castellciutat, actualment pertany terme municipal de la Seu d'Urgell, comarca de l'Alt Urgell). (Full 253).}

Després de fer l'aturada anterior, cal retornar a la cruïlla de Montferrer, per tal de seguir cap a la Seu d'Urgell, seguint la carretera N - 260. Més endavant, en arribar al trencall de Castellciutat, caldrà anar-hi per tal de fer la darrera aturada, a uns $5 \mathrm{Km}$ de l'altra.

En aquest indret haurem anat circulant per entre els materials neògens i quaternaris de la Depressió de l'Urgellet, per on estem ara situats. Tot i així, aquest indret es troba sobre un aflorament dels nivells esquistosos de I'Ordovicià, els quals pertanyen a la Unitat dels Apilaments de la Zona Axial Pirinenca, i que constitueixen una cunya, entre els materials terciaris (del Neogen), i dels quaternaris, que omplen la Depressió de I'Urgellet. Aquesta depressió s'estén per llevant entorn a la població de la Seu d'Urgell; i per ponent entorn a les poblacions d'Arfà i d'Adrall, com anirem veien a través del recorregut cap a la parada següent.

Així, des d'aquest indret, es pot observar amplament la situació de la Depressió de I'Urgellet, la qual correspon a una fosa tectònica, ubicada entre l'abans esmentada Unitat dels Apilaments de la Zona Axial Pirinenca (la qual es troba situada al lloc on ara som, i que s'estén molt més amplament cap al Nord, i que es troba constituït per materials paleozoics), i els relleus del Mantell del Cadí (amb afloraments de materials paleozoics, mesozoics i cenozoics, el qual s'estén cap al Sud, tot constituint la serra del mateix nom). (fotografia 2). 


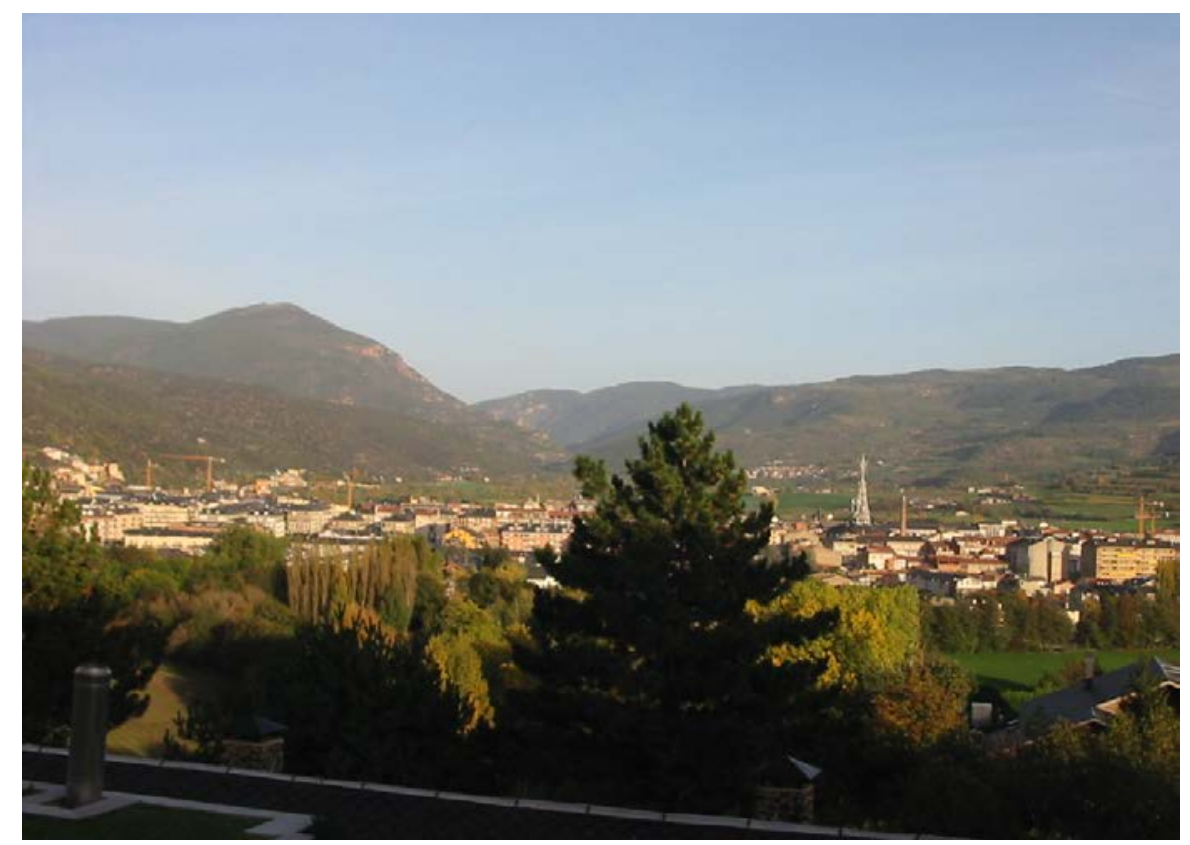

Fotografia 2. La Depressió de I’Urgellet, amb la Seu d’Urgell

\subsection{Parada 3 - CONDICIONAL. MINA DE BELLIDA, (Ansovell, terme municipal d’Ansovell - Cava, comarca de I’Alt Urgell). (Full 216).}

Després de fer l'aturada anterior, cal seguir cap a la Seu d'Urgell, que ens caldrà travessar per tal de seguir per la N-260, cap al llevant. Aviat passarem pels trencalls d'Alàs, Estamariu Bescaran, Torres i Arsèguel. També haurem passat pel costat de la Quera. Així, en aquest trajecte, en arribar al Pont d'Arseguel, cal seguir per la carretera que se'n va cap a Arsèguel, iniciant una fillola. Per aquesta carretera s'anirà després cap a les immediacions d'Ansovell. Poc abans d'arribar-hi, es trobarà el trencall, per la dreta, que se'n va cap a Cal Rill, per anar des d'aquí cap a Bellida, per on farem una nova aturada, a uns $12 \mathrm{Km}$ de l'inici de la fillola, i a uns $22 \mathrm{Km}$ de la parada anterior.

En aquest recorregut, hem anat circulant, fins arribar al trencall d’Alàs, per la Depressió de I'Urgellet. Tot seguit, haurem entrat a la zona de contacte entre la Zona Axial Pirinenca (al Nord,) i el Mantell del Cadí (al Sud). Així, ens mourem per la zona de fractures que posen en contacte les dues sots-unitats dels Pirineus. Per d'altra banda, en tots dos casos ens haurem trobat amb afloraments dels materials paleozoics: de l'Ordovicià al Devonià, segons els llocs. Més endavant, en anar des del Pont d'Arseguel fins a l'indret de l'aturada, ens endinsarem en el Mantell del Cadí, on ens trobem ara, a l'indret de l'aturada.

En aquest Iloc afloren uns nivells de calcàries del Devonià. Entre aquests nivells es troben unes mineralitzacions ferruginoses associades a skarn, que van esser explotades. Entre els minerals presents cal fer esment dels següents: PIRROTINA (indicis), GOETHITA (terrosa, limonítica) i MAGNETITA. També es fa palesa la presència d'indicis de l'amfíbol HEDENBERGITA, entre altres minerals.

Sembla ser que en aquest lloc va haver-hi divers intents d'explotació d'aquestes mineralització, sense gaire èxit. Algunes d'elles van realitzar-se segles enrere, com la que mostrem a continuació. (fotografia 3). 


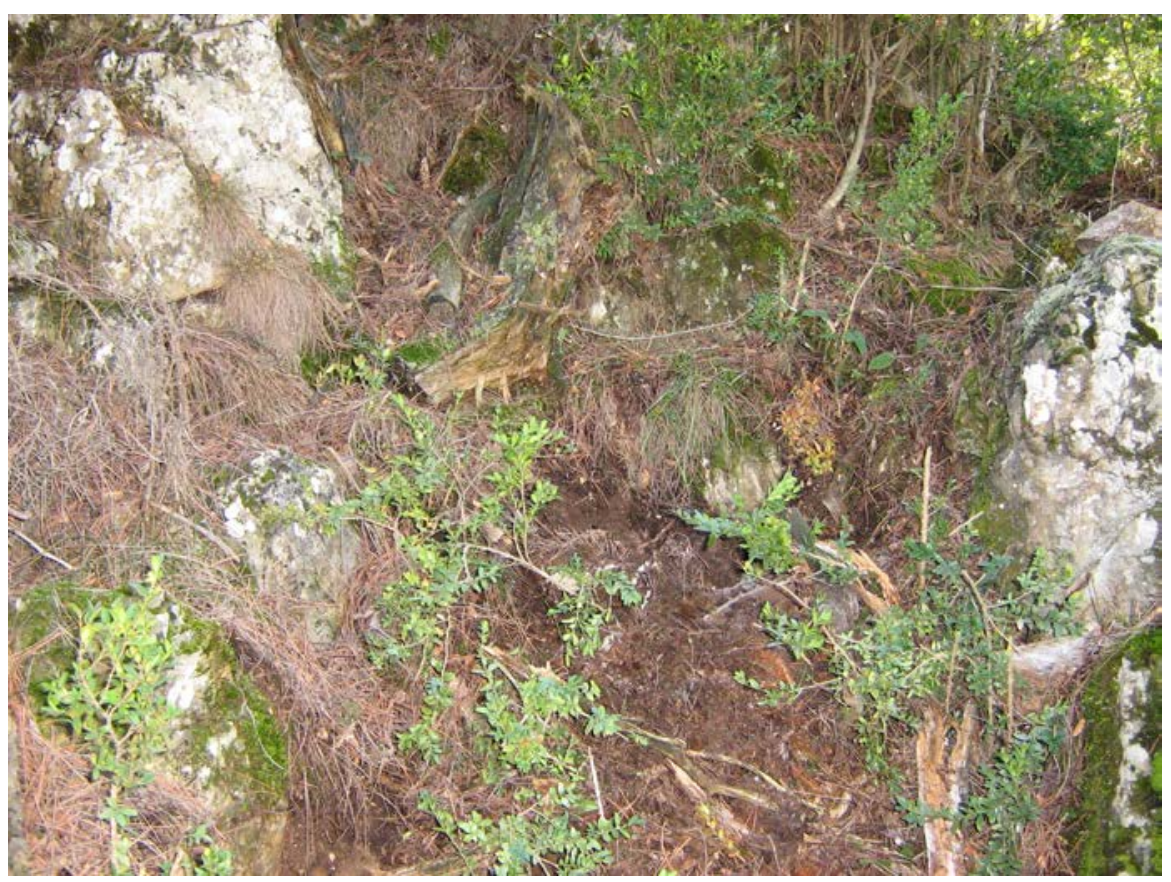

Fotografia 3. Restes de l'antiga explotació

Per altra banda, des d'aquest lloc, mirant cap a llevant, cap a l'antic poble de Vinyoli, i cap al Coll de Se, es pot veure una interessant fractura, que posa en contacte els materials del Devonià amb els del Permotries.

\subsection{Parada 4. ESFONDRAMENT DE CAVA, (Cava, terme municipal d'Ansovell - Cava, comarca de l'Alt Urgell). (Full 216).}

Després de realitzar la parada anterior, cal tornar enrere, fins arribar a Cal Rill, per on hem passat anteriorment en anar cap a la mina. En aquest indret podem fer una nova parada, tot mirant cap a el proper poble de Cava. D'aquest mateix municipi. Aquest poble es troba situat a uns $4 \mathrm{Km}$ cap al SE d'on ara som.

Des d'aquí mirant cap a Cava, es pot veure un interessant sinclinal, trobant-se Cava al seu extrem SW. Aquest sinclinal, més aviat lax, es troba constituït per nivells carbonatats de calcaries del Devonià. (fotografía 4). 


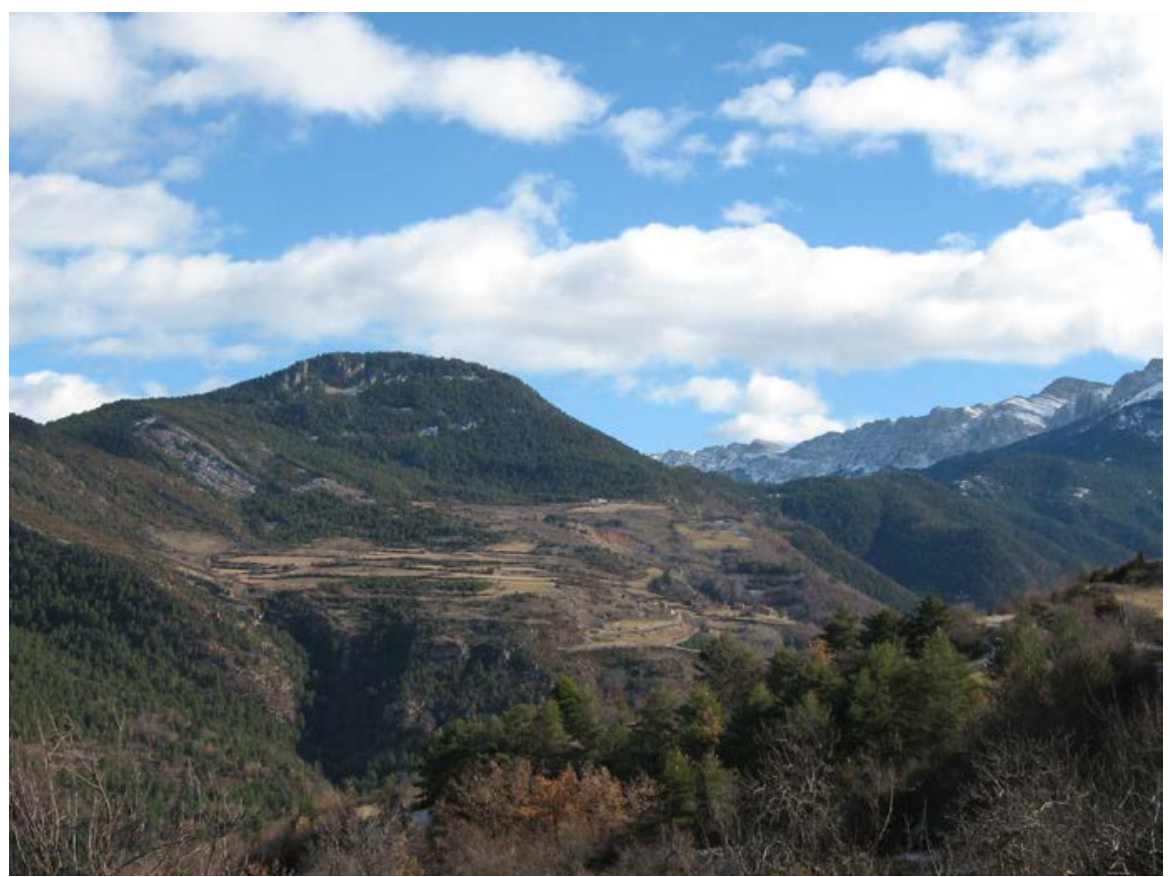

Fotografia 4. Plec de Cava

Per altra banda, es veu la cicatriu d'una esllavissada que es va produir fa anys, sobre l'esmentat poble. (fotografia 5).

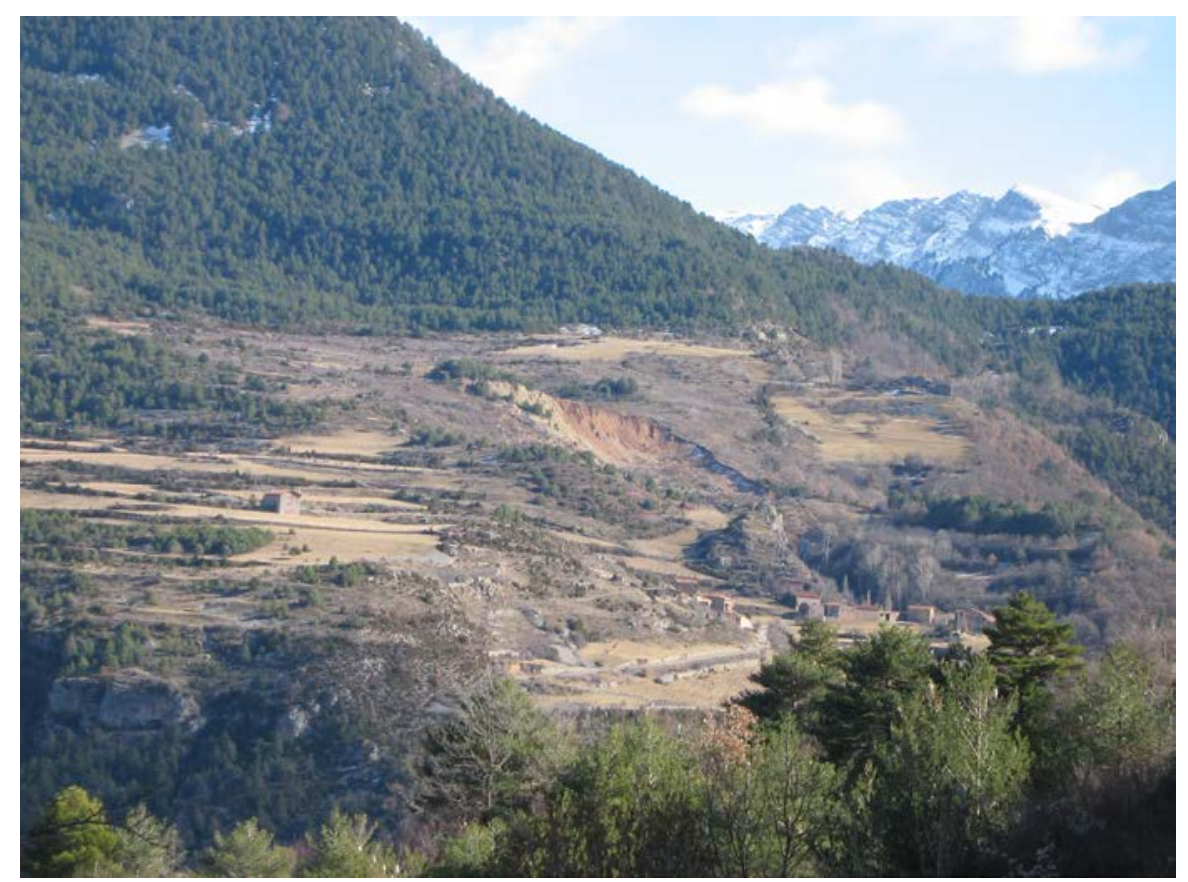

Fotografia 5. Esfondrament de Cava. Es veu sobre el poble, al centre de la foto 


\subsection{Parada 5. ESFONDRAMENT DEL PONT DE BAR, (Pont de Bar, actualment pertany terme municipal d'Aristot - Toloriu, comarca de I'Alt Urgell). (Full 216).}

Després de fer l'aturada anterior, cal retornar al Pont d'Arseguel, a la carretera N - 260, per tal de seguir cap a llevant (cap a Puigcerdà). Seguint en aquest sentit, aviat arribarem al Pont de Bar, per on farem aquesta nova aturada. Així, haurem recorregut uns $16 \mathrm{Km}$ més.

En aquest recorregut, hem anat circulant, la zona de fractures que posen en contacte les dues sots-unitats dels Pirineus (la dels Apilaments Antiformes de la Zona Axial Pirinenca, al Nord i la del Mantell del Cadí, al Sud). Per d'altra banda, en tots dos casos ens haurem trobat amb afloraments dels materials paleozoics: de l'Ordovicià al Devonià, segons els llocs.

En arribar a l'indret de l'aturada, a Pont de Bar, podrem veure les restes de la gran esllavissada de fa uns anys, que va mig sepultar el poble. Es tracta d'uns sediments quaternaris (derrubis i morrena glacial), assentats sobre terrenys paleozoics molt fracturats. Tot plegat, durant un temporal va esllavissar-se sobre el poble, taponant el Segre. (fotografia 6).

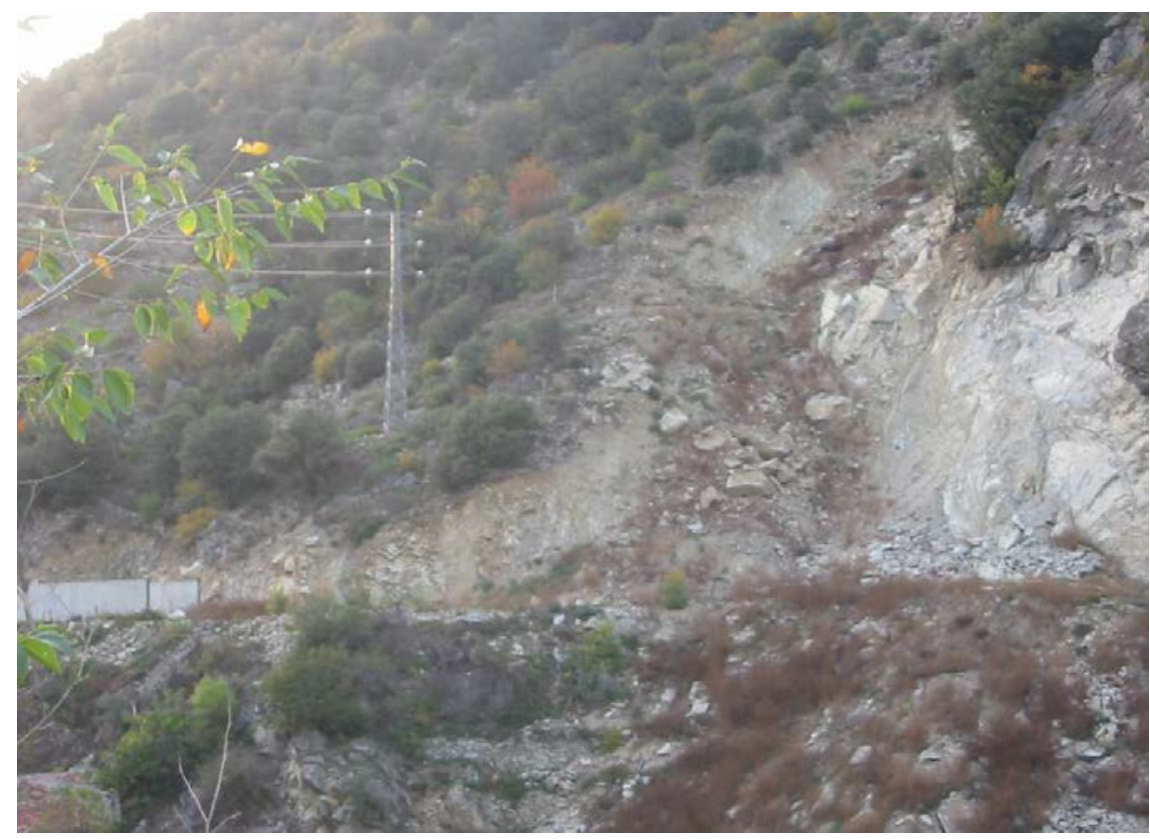

Fotografia 6. Afloraments paleozoics i quaternaris de Pont de Bar. Restes de l'esllavissada 


\subsection{Parada 6. EXPLOTACIÓ DE SAULÓ DELS ARENYS DE BAR, (Arenys de Bar, els; actualment pertany terme municipal d'Aristot - Toloriu, comarca de l'Alt Urgell). (Full 216).}

Després de fer l'aturada anterior, cal seguir per la carretera N-260, tot anant cap a ponent. Així, aviat es passarà pels trencalls de Toloriu i Bar, baixant després la carretera cap al Segre, que es creuarà ben aviat. Una mica més endavant de deixar el Càmping a la dreta, caldrà parar en una explanada (a l'esquerra), en un tram abandonat de la carretera. Així, en aquest recorregut haurem fet uns $2 \mathrm{Km}$ més.

En aquest recorregut, hem anat circulant per entre els materials paleozoics esmentats a la parada anterior. Per d'altra banda, ara ens haurem trobat en uns afloraments granodiorítics, que són els que afloren a l’indret de l'aturada.

En aquest Iloc es pot veure una recent explotació de les granodiorites descompostes per la meteorització (dels anomenats saulós). Aquesta descomposició ha donat lloc a unes arenes arcòsiques, al transformar-se els feldspats de les roques ígnies en caolí, quedant així lliure el quars. Es tracta d’un bon àrid per a la construcció.

Per altra banda, en aquest indret es pot veure un bon tall, i ens podem fixar en el contacte que hi ha a la part alta de la pedrera. En aquest lloc hi afloren unes roques carbonatades del Devonià, les quals es troben alterades per la intrusió de les granodiorites. Aquest fenomen es un bon exemple de skarn. (fotografia 7).

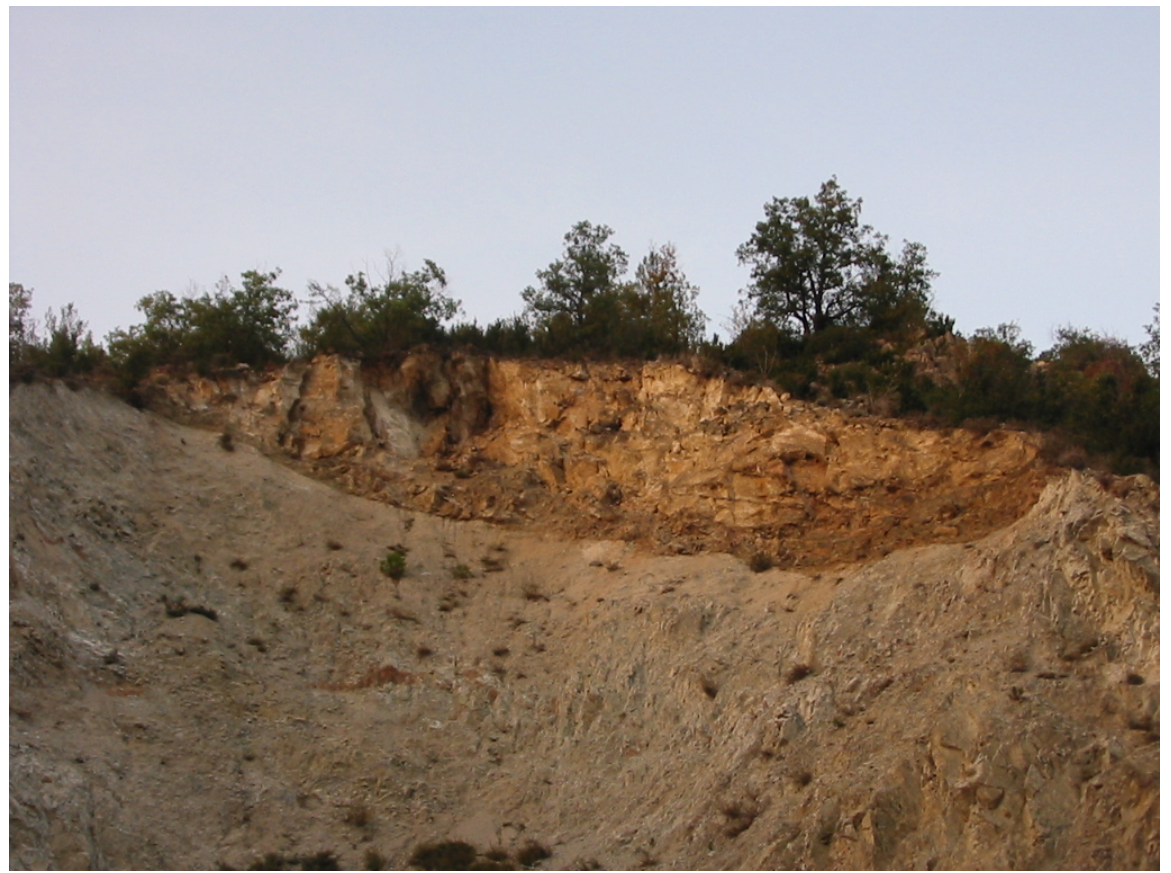

Fotografia 7. Les granodiorites de l'explotació de sauló

i el seu contacte amb les calcàries del Devonià 


\subsection{Parada 7. MINA DE FERRO DELS ARENYS DE BAR, (Arenys de Bar, els; actualment pertany terme municipal d'Aristot - Toloriu, comarca de l'Alt Urgell). (Full 216).}

Després de fer l'aturada anterior, cal fer un breu recorregut, de molt menys de 0 ' $2 \mathrm{Km}$, per tal d'anar cap a l'indret on farem una nova aturada, molt prop de l'anterior.

En aquest recorregut, després de travessar les granodiorites de la parada anterior, haurem trobat les calcàries del Devonià que ja hem esmentat anteriorment. Així, haurem penetrat a la zona de skarn, on ara ens trobem.

En aquest lloc hi ha una interessant mineralització associada a skarn, al contacte entre les calcaries i dels granodirites. Aquesta mineralització ha donat lloc a la formació de diferents silicats, com: HEDENBERGITA, GRANAT i EPIDOTA. Tanmateix s'han originat minerals metàl-lics com els següents: CALCOPIRITA, PIRITA i PIRROTINA; així com indicis d'ESFALERITA i de GALENA. Amb els anteriors també es troben altres minerals com la SCHEELITA. Per l'alteració del sulfurs de ferro (especialment de la pirita i de la pirrotina) s'han format diversos minerals com la GOETHITA (terrosa i limonítica), la FERROHEXAHIDRITA, la MELANTERITA i el SIDEROTIL. En qualsevol cas, cal parlar de l'espectacularitat de les eflorescències dels tres sulfats de ferro acabats d'esmentar.

Cal dir que en aquest indret es van intentar explotar el sulfurs de ferro (la PIRROTINA, molt abundant), però sense cap mena d’èxit. (fotografia 8).

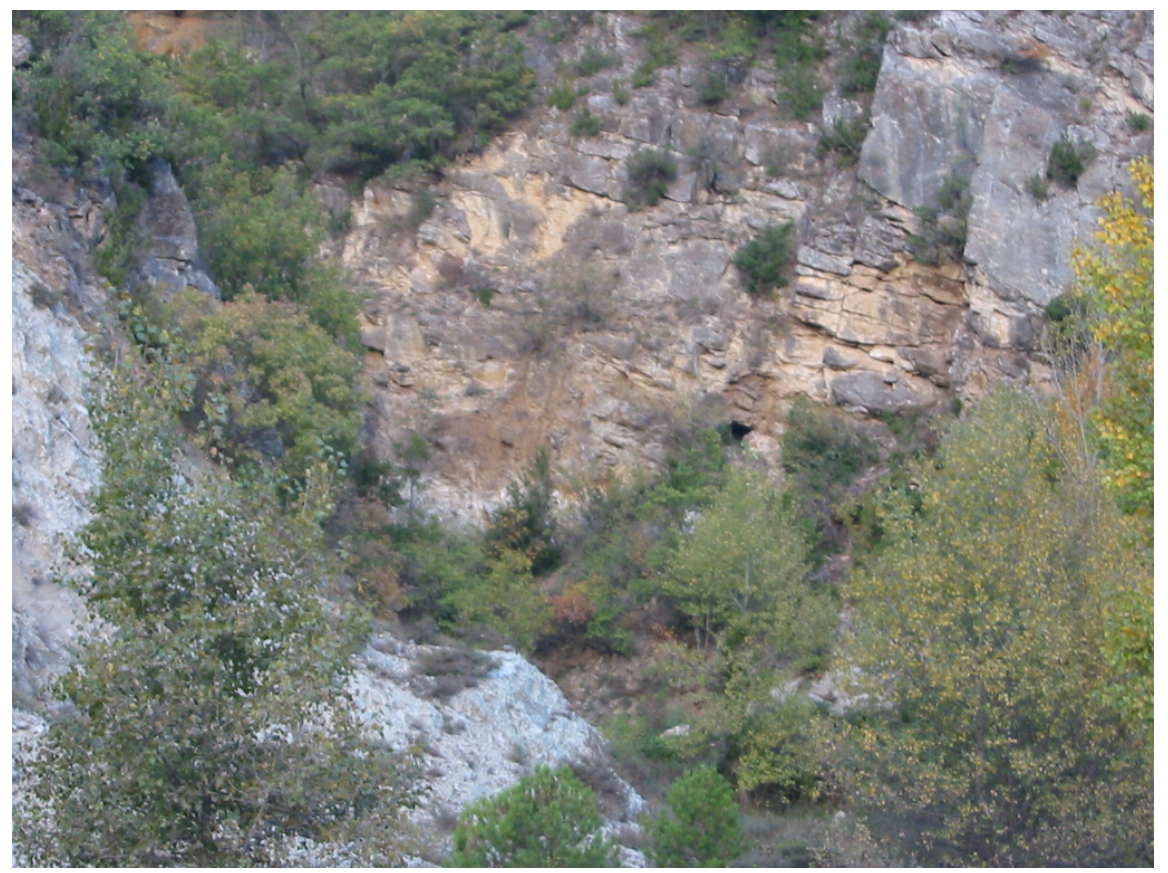

Fotografia 8. El skarn, en el contacte entre les granodiorites (primer terme) i les calcàries del Devonià (segon terme). Dintre d'aquestes es pot veure una bocamina 


\subsection{Parada 8. MINA DE LES CAULES, (Musser, pertany terme municipal de Lles, comarca de la Cerdanya). (Full 216).}

Després de fer l'aturada anterior, cal fer un breu recorregut, de poc mes de $2 \mathrm{Km}$, per tal de seguir cap a llevant per la carretera N-260. Poc després de sobrepassar els Arenys de Bar, deixarem la comarca de l'Alt Urgell, passant a la de la Cerdanya. Després, en arribar al primer túnel, trobarem un corriol que surt per la dreta, passant per sobre del túnel. Aquest corriol ens durà cap a la Mina de les Caules, on farem una nova aturada.

En aquest recorregut, després de travessar de nou les granodiorites, haurem tornat a trobar les calcàries del Devonià. Així, haurem penetrat a la zona de skarn, on ara ens trobem. En aquest lloc hi ha una interessant mineralització associada a skarn, al contacte entre les calcaries i dels granodiorites.

Aquesta mineralització ha donat lloc a la formació de silicats, com: HEDENBERGITA, GRANAT i EPIDOT. També s'han originat els següents minerals metàl-lics: CALCOPIRITA, PIRITA i PIRROTINA; així com indicis d'ESFALERITA i de GALENA. Amb els anteriors també es troben altres minerals com la SCHEELITA. De tots ells, es van intentar explotar el sulfurs de ferro (la PIRROTINA, molt abundant), però sense cap mena d'èxit.

Per l'alteració del sulfurs de ferro (especialment de la pirita i de la pirrotina) s'han format diversos minerals com la GOETHITA (terrosa i limonítica), la FERROHEXAHIDRITA, la MELANTERITA i el SIDEROTIL. En qualsevol cas, cal parlar de l'espectacularitat de les eflorescències dels tres sulfats de ferro acabats d'esmentar.

\subsection{Parada 9 - CONDICIONAL. ESTRET DE MARTINET, (Martinet, actualment del terme municipal de Montellà de Cadí i Martinet, comarca de la Cerdanya). (Full 216).}

Des de la parada anterior, cal seguir per la carretera $N-260$, anant cap a llevant. Per aquesta, aviat s'arribarà a les immediacions de Martinet. Poc abans, s'arribarà a la cruïlla de la carretera de Lles. Aquí podem fer una nova aturada, a uns $3-4 \mathrm{Km}$ de l'anterior.

En aquest recorregut s'ha circulat per la zona de fractures que separa els materials paleozoics del Mantell del Cadí (situats al Sud), amb els també paleozoics dels Apilaments Antiformes de la Zona Axial Pirinenca, situats al Nord.

Així, aquí es fan palesos els afloraments dels materials esquistosos del Carbonífer, els quals es troben situats entre Martinet i l'aturonat poble de Montellà del Cadí. Per sobre d'aquests, tot anant cap a Estana, ja es trobarien els trams vermells dels materials detrítics del Permo-Tries, situant-se aquests dintre del Mantell del Cadí. 


\subsection{Parada 10. TÚNEL DE PRULLANS, (terme municipal de Prullans, comarca de la Cerdanya). (Full 216).}

Després de fer l'atirada anterior, cal continuar cap a llevant per la carretera nacional $\mathrm{N}-260$. Per aquesta via, aviat s'arribarà a la població de Martinet, que caldrà creuar. Després caldrà seguir cap a llevant, arribant aviat al túnel de Prullans. Per aquest indret, ens caldrà fer una aturada; just a la sortida, per l'esquerra, es veurà el tram antic de la carretera. Just, en aquest lloc, caldrà fer l'aturada, a uns $7 \mathrm{Km}$ de l'anterior.

En aquest recorregut s'ha circulat inicialment entre els aflorament dels materials paleozoics esmentats als recorreguts anteriors, tot i que ja es van fent palesos els sediments neògens, els quals reblen la Depressió de la Cerdanya. Tot i així, prop de l'indret de l'aturada, es fan palesos els materials paleozoics del Mantell del Cadí, els quals es troben en contacte per falla amb els dels Apilaments Antiformes de la Zona Axial Pirinenca.

Així, aquí es fan palesos els afloraments dels materials esquistosos del Silurià, els quals es troben en contacte per falla amb els del Devonià. Precisament, a la bretxa de falla es fa palesa una interessant mineralització, amb HIDROCINCITA i MELANTERITA com a minerals més ostensibles. Es tracta doncs, d'una típica mineralització d’alteració de sulfurs primaris. (fotografia 9).

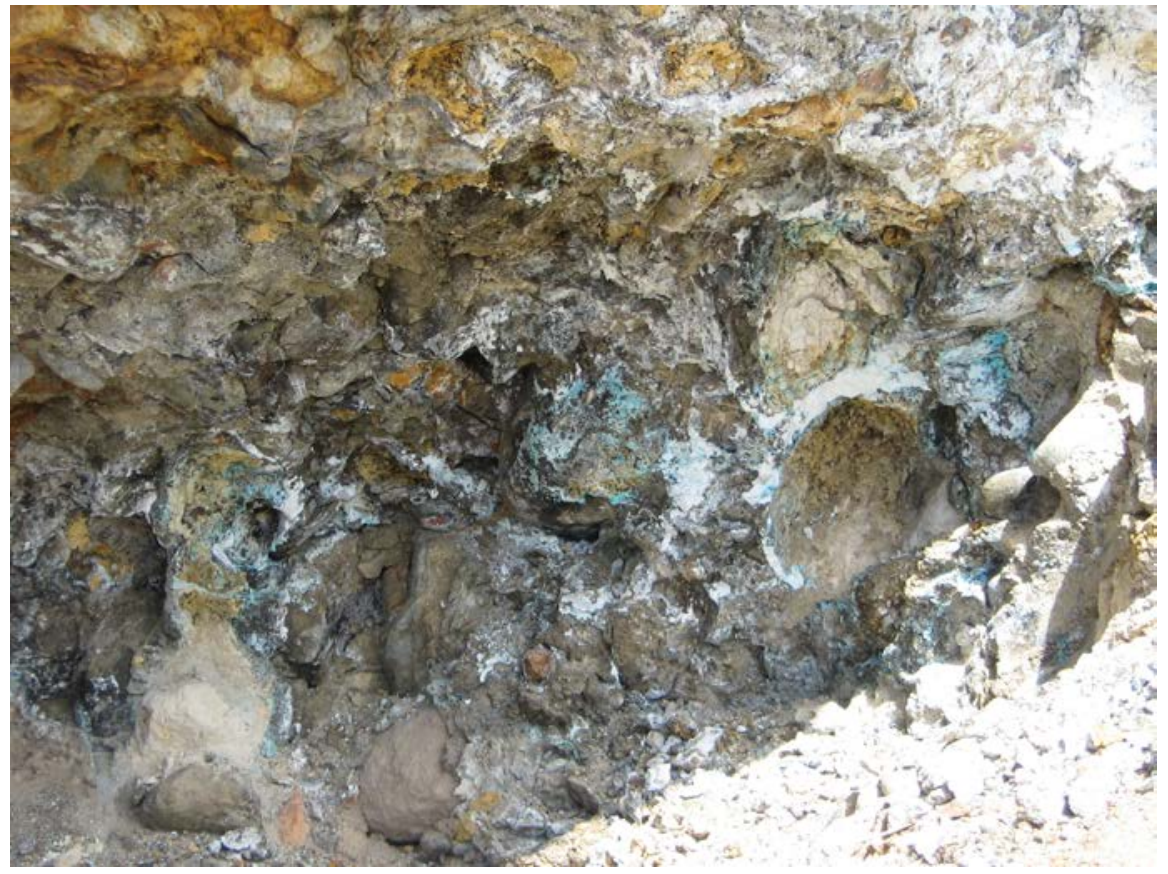

Fotografia 9. Un aspecte d'aquestes mineralitzacions

Xaragall.2015 n.7 | Recorregut de recerca geològica per les comarques de l'Alt Urgell i de la Cerdanya: des de Montferrer i Castellciutat a la Seu d’Urgell, Pont de Bar, Martinet, a Prullans i a Bellver de Cerdanya 


\subsection{Parada 11 - CONDICIONAL. FORN DE CALÇ DE PRULLANS, (terme municipal de Prullans, comarca de la Cerdanya). (Full 216).}

Després de fer l'atirada anterior, cal continuar cap a llevant per la carretera nacional $\mathrm{N}-260$. Per aquesta via, aviat s'arribarà a les immediacions de població de Prullans. Quasi en arribarhi, farem una nova aturada dintre d'aquest itinerari. La farem a uns $3 \mathrm{~km}$ de l'anterior, aproximadament

En aquest recorregut, inicialment, hem trobat afloraments dels materials anteriors; tot i així, poc a poc hem entrat a la Depressió de la Cerdanya i hem començat a trobar sediments terrígens del Neogen, del miocè a l'Holocè.

En aquest indret hi ha les restes d'un Forn de Calç, el qual forma part del Patrimoni Miner de la comarca de la Cerdanya.

\subsection{Parada 12 - CONDICIONAL. IMMEDIACIONS DEL PONT DE BELLVER, (terme municipal de Bellver de Cerdanya, comarca de la Cerdanya). (Full 216).}

Després de fer l'atirada anterior, cal continuar cap a llevant per la carretera nacional $\mathrm{N}-260$. Per aquesta via, aviat s'arribarà a la població de Bellver de Cerdanya (una de las capitals d'aquesta comarca). En arribar-hi, farem una nova aturada dintre d'aquest itinerari. La darrera. Així, des de l'anterior, haurem efectuat un recorregut proper als $3 \mathrm{Km}$, per tal d'arribar fins aquí.

En aquest recorregut, hem anat entrant plenament dintre de la Depressió de la Cerdanya. Així, s' hauran fet palesos per arreu, els afloraments dels materials neògens que la reblen, del Miocè a l'Holocè. Aquests materials són terrígens.

En aquest indret, estem situats prop del Segre. Cal destacar els abundants depòsits fluvials depositats per aquest riu: les terrasses fluvials del Pleistocè i de l'Holocè, que hem anat trobant en aquest recorregut.

En aquest indret finalitza el recorregut de l'itinerari

Xaragall.2015 n.7 | Recorregut de recerca geològica per les comarques de l'Alt Urgell i de la Cerdanya: des de Montferrer i Castellciutat a la Seu d’Urgell, Pont de Bar, Martinet, a Prullans i a Bellver de Cerdanya 


\section{Bibliografia}

GUIMERÀ, J. et altri (1992).- Geologia (II), Història Natural dels Països Catalans, Vol. 2, 547 pag. Enciclopèdia Catalana, S.A. Barcelona.

MATA-PERELLÓ, J.M. (1991).- Els Minerals de Catalunya. Arxius de la Secció de Ciències de I'Institut d'Estudis Catalans, vol.47, 545 pàgines. Barcelona.

MATA-PERELLÓ, J.M. (1995).- Itinerari Geològico-Mineralògic per l’Alt Urgell: d’Oliana a la Palanca de Noves i al Pla de Sant Tirs. Selecc. d'itineraris geològico-mineralògics per l'Alt Urgell, ... pp. 3-12. Manresa.

MATA-PERELLÓ, J. M. (1998).- Recorregut de recerca geològica per les comarques de l'Alt Urgell (Urgell Mitjà) i Pallars Jussà: des d'Oliana a la Palanca de Noves i des del Coll de Nargó a Isona. Xaragall, sèrie $B, \mathrm{n}^{\circ} 104,11$ pag. Manresa.

MATA-PERELLÓ, J. M. (2007).- Recorregut de recerca geològica i minera per les comarques de l'Alt Urgell i de la Cerdanya: des d'Adrall a la Seu d’Urgell, Ansovell i All. Inèdit. 12 pàgines. Manresa.

MATA-PERELLÓ, J. M. (2008).- Recorregut de recerca geològica per la comarca de l'Alt Urgell: des d’Adrall a la Seu d'Urgell, Pont de Bar i els Arenys de Bar. Inèdit. 8 pàgines. Manresa.

MATA-PERELLÓ, J. M. (2011).- Recorregut de recerca geològica i mineralògica per les comarques de la Cerdanya i de l'Alt Urgell: de d'Alp cap a Pi, Cortàs, Talltendre i Martinet; i des de Martinet cap al Pont de Bar. Inèdit. 14 pàgines. Manresa.

MATA-PERELLÓ, J. M. i MONTANÉ GARCIA, P.(2002).- Recorregut de recerca geològica per les comarques de la Noguera i de l'Alt Urgell (Urgell Mitjà): des de Folquer a Peramola, a Oliana i a la Palanca de Noves. Inèdit. Manresa.

MATA-PERELLÓ, J. M. i MONTANÉ GARCIA, P. (2004).- Recorregut de recerca geològica per la comarca de l'Alt Urgell: des de Peramola a Oliana, a la Palanca de Noves i a Adrall. Inèdit. 20 pag. Manresa.

RIBA ARDERIU, O. et altri (1976).- Geografia Física dels Països Catalans. Edit Ketres. Barcelona. 